\title{
SYNANAIREĨSTHAI $\boldsymbol{E}$ AUFHEBEN ${ }^{1}$ Alguns aspectos das dialéticas platônica e hegeliana
}

\author{
Leonardo Vieira ${ }^{2}$ \\ leonarva@terra.com.br
}

RESUMO Explico, primeiramente, lançando mão dos textos de Platão, Aristóteles e Sexto Empírico, o sentido de synanaireĩsthai no contexto da identificação das dimensões do ser e das faculdades da alma. Depois, passo, então, ao comentário hegeliano da dialética platônica. Nesta parte do texto, discuto os significados de synanaireĩsthai e Aufheben e algumas diferenças entre as dialéticas platônica e hegeliana.

Palavras-Chave Synanaireĩsthai, Aufheben, Dialética, Faculdades da alma

ABSTRACT Firstly, by using Plato's, Aristotle's and Sextus Empiricus' texts, I explain the meaning of synanaireĩsthai in the context of the dimensions of being and soul's affections. After that, I proceed then to Hegel's commentary on Plato's dialectic. In this part of the text, I discuss the meanings of synanaireĩsthai and Aufheben as well as some differences of Hegel's and Plato's dialectics.

Keywords Synanaireĩsthai, Aufheben, Dialetic, Soul's affections

1 Como capítulo de livro, este artigo foi publicado originalmente, em língua alemã, no livro em homenagem ao sexagésimo aniversário do Prof. Hans-Georg Flickinger (VIEIRA, 2004), orientador de vários doutorandos brasileiros na Alemanha, inclusive do autor deste artigo, também professor e conferencista em universidades brasileiras. Presto aqui minha homenagem ao Prof. Flickinger tanto por sua sempre gentil e calorosa acolhida de estudantes brasileiros em solo germânico e orientação acadêmica sempre rigorosa e inspiradora. $\mathrm{O}$ estilo conciso e direto do artigo é resultado das diretrizes estabelecidas pelos editores a todos os autores visando a composição do livro em foco.

2 Departamento de Filosofia da UFMG. Recebido em 27/08/2009 e aprovado em 02/03/2010.

KRITERION, Belo Horizonte, nº 121, Jun./2010, p. 195-214. 
Tendo em vista sua compreensão, a concepção hegeliana da dialética pode ser colocada no contexto de toda a história da própria dialética, dentro da qual sua interpretação particular da dialética, justamente em virtude do confronto com interpretações alternativas daquilo que nelas é a dialética, adquire contornos definidos. Também interessante e fecundo é o acompanhamento da discussão de Hegel com a dialética clássica. Uma outra variante consiste em proceder a uma investigação da Lógica hegeliana, a fim de levar a cabo, a partir de dentro, i.e., partindo do próprio movimento da ideia, um confronto semelhante ao que acima foi citado, o qual anteriormente, no entanto, foi produzido a partir de fora do movimento da ideia. ${ }^{3}$

Pretendo tomar um outro caminho, porque tenho um outro propósito. Em primeiro lugar, não quero ocupar-me com uma discussão sobre a totalidade da Lógica hegeliana. Diferentemente, concentro-me na avaliação hegeliana da dialética platônica. Em segundo lugar, lido, dentro da complexa temática das dialéticas platônica e hegeliana, com os significados de synanaireĩsthai e Aufheben. Em terceiro lugar, não quero repetir uma simples reprodução da crítica de Hegel à dialética platônica. Faço uso, portanto, dos resultados disponíveis do novo paradigma de pesquisa sobre a filosofia de Platão, a fim de também avaliar a compreensão hegeliana da dialética platônica.

Em razão disso, procuro, primeiramente, lançando mão dos textos de Platão, Aristóteles e Sexto Empírico, esclarecer o sentido de synanaireĩsthai. Depois passo, então, ao comentário hegeliano da dialética platônica, no qual os significados de synanaireĩsthai e Aufheben são debatidos, mas também algumas diferenças entre ambos os modos dialéticos de investigação são discutidas.

\section{Platão: Synanaireĩsthai}

Do ponto de vista da construção dos níveis do ser e sua complexa dialética, Gaiser soube explicar como ela é levada a cabo mediante a articulação entre matemática e ontologia. ${ }^{4}$ Synanaireĩsthai é a palavra ressaltada por Gaiser em sua interpretação de Platão e traduzida como estar-cosuprassumido (Mitaufgehohensein). ${ }^{5}$ Interpretação e tradução não são oriundas, no entanto, dos próprios textos de Platão, mas do relato de Sexto Empírico sobre os pitagóricos. Segundo o mesmo Gaiser, todavia, o relato recupera, na verdade, as comunicações orais de Platão, as quais foram erroneamente associadas 
por Sexto Empírico à posição dos pitagóricos. Posteriormente, no entanto, a vinculação com o texto platônico será feita tanto no livro de Gaiser quanto no transcurso desse trabalho.

O relato de Sexto Empírico aborda os níveis do ser e a dialética de construção desses níveis. Em uma primeira e simplificada apresentação, são listados três níveis do ser: corpos sensivelmente perceptíveis, corpos apreendidos apenas pelo pensamento (noetá) e inacessíveis aos sentidos (ádela), objetos incorpóreos (tà asómata). ${ }^{6}$ Os "filósofos genuínos" deveriam adotar um procedimento semelhante à análise da linguagem (lógos), segundo a qual o que compõe a linguagem é a palavra. A palavra, por sua vez, tem sílabas como seus componentes. Essas são formadas pelo que Sexto Empírico denomina "os elementos da língua escrita". ${ }^{7}$ Esse procedimento consiste, pois, na redução de um objeto a seus elementos constituintes. Aplicado ao estudo dos níveis do ser, isto significa a redução dos corpos sensivelmente perceptíveis aos corpos apreendidos apenas pelo pensamento e inacessíveis aos sentidos; esses, por sua vez, se decompõem, finalmente, em objetos incorpóreos, os quais não são mais regressivamente dissolvidos em um novo pressuposto. Há, evidentemente, uma relação de unilateralidade entre o plano supraordenado e o subordinado, de tal forma que esse não pode existir sem aquele.

Posteriormente, a investigação de Sexto Empírico sobre a hierarquia dos níveis do ser é aprofundada mediante recurso à matemática. Os corpos sensivelmente perceptíveis (1) não podem ser pensados e existir sem as figuras tridimensionais, extensas em todos os lados (2). Essas, por sua vez, carecem da superfície ou do plano (3) como aquilo que antecede às figuras tridimensionais. A superfície, por seu turno, tem como pressuposto a linha (4), a qual é precedida pelo número (5). Esse, finalmente, é produto do Uno e da Díade Indeterminada (6). ${ }^{8}$ Em virtude dessa decomposição, o ser negado (anaireĩsthai) do gênero (génos) implica necessariamente o ser-conegado (synanaireĩsthai) de todas as ideias ou espécies que estão sob o poder organizatório do gênero, uma vez que aquelas dependem deste. Assim sendo, também a linha é co-negada, se o número é negado, o qual, perante a linha,

6 SEXTUS Empiricus. Against the physicists II, 253; GAISER, 1998, p. 82, 497; Testimonia Platonica, Nr. 32. A tradução do texto grego ocorre sob minha responsabilidade, embora tenha também me orientado pela tradução de Gaiser. Nas citações manterei a ortografia das edições dos textos por mim utilizadas.

7 SEXTUS Empiricus. Against the physicists II, 249.

8 SEXTUS Empiricus. Against the physicists II, 259-262; GAISER, 1998, p. 83, 498s; Testimonia Platonica, Nr. 32. Limito-me a apresentar a série de níveis do ser, sem, no entanto, abordar as razões detalhadas para o seu estabelecimento, já que o lidar com elas nos levaria para além dos limites impostos aos textos dessa Festschrit. Para tanto, indico o relato de Sexto Empírico, o comentário e a tradução de Gaiser. 
atua como gênero. ${ }^{9}$ Aqui, synanaireĩsthai apresenta o seu caráter negativo, vinculando necessariamente a negação do plano superior com a negação dos planos que lhe são hierarquicamente subordinados.

Em A República os níveis hierárquicos do ser são analisados na perspectiva da alma ascendendo ao princípio de tudo, e um outro aspecto de synanaireĩsthai, além da negação acima ressaltada, é focalizado, a saber, na preservação e conservação do que foi negado. A fim de sublinhar esse novo sentido de synanaireĩsthai, é importante vincular o texto sobre a linha do saber $(509 \mathrm{c}-$ 511 e) com a passagem que esclarece o método dialético $(533 \mathrm{c}-535 \mathrm{a})$. O texto sobre a linha do saber articula os pathémata (faculdades) da alma com os objetos com os quais cada uma dessas faculdades lida. Assim, a imaginação (eikasía), a menos potente dessas faculdades, tem como objeto as imagens ou sombras das coisas sensíveis, ao passo que a crença (pístis) refere-se aos próprios objetos sensíveis. Ambas as faculdades dizem respeito à opinião (dóxa), incapaz de indicar nela mesma um critério seguro para suas afirmações. Em oposição à opinião está a ciência (epistéme), a qual, por sua vez, subdivide-se também em dois momentos: conhecimento dianoético ou mediano (diánoia) e conhecimento noético ou intelecção (nóesis). O primeiro tem diante de si os objetos matemáticos, enquanto que o segundo tematiza as ideias, suas relações e sua vinculação com a Ideia do Bem. Ambas(os) tratam do mundo suprassensível. ${ }^{10}$

A relação dos seis níveis do ser citados pelo relato de Sexto Empírico com as quatro faculdades de conhecimento expostas em A República tornase evidente, se a relação das dimensões espaciais com as faculdades de conhecimento tratada no De anima é levada em consideração - relação essa constatada por Gaiser ${ }^{11}$ e que reproduz parte do ensinamento oral de Platão. As dimensões espaciais são unidade ou ponto, linha, plano e corpo, e as quatro faculdades de conhecimento citadas por Aristóteles recebem, de fato, outros nomes, mas, no fundo, correspondem aos pathémata da alma descritos em $A$ República - nóesis, diánoia, pístis e eikasía: noũs (conhecimento noético), epistéme (ciência), dóxa (opinião) e aísthesis (percepção sensível). ${ }^{12}$ A relação de analogia é por Gaiser apresentada da seguinte forma: conhecimento noético refere-se à unidade ou ao ponto, ciência à linha, opinião ao plano e, finalmente, percepção sensível ao corpo.

9 SEXTUS Empiricus. Against the physicists II, 269; GAISER, 1998, p. 500; Testimonia Platonica, Nr. 32.

10 VIEIRA, 2002, p. 49.

11 ARISTOTELIS, De anima, 404b, 16-27; GAISER, 1998, p. 44; Testimonia Platonica, Nr. 25 A.

12 GAISER, 1998, p. 91s. Essas traduções divergem parcialmente da tradução para o alemão feita por Gaiser: noũs (Einsicht: conhecimento racional discursivo e intuitivo), epistéme (Verstehen: compreender), dóxa (Meinung: opinião) e aísthesis (sinnliche Wahrnehmung: percepção sensível). 
Em virtude disso, o texto da A República, mediatizado pelo texto de Aristóteles, pode, então, ser vinculado ao relato de Sexto Empírico da seguinte forma: os níveis do ser (1) até (3) formam a contraparte ontológica das faculdades que se ocupam com o mundo sensível. Enquanto a eikasía ou a aísthesis aristotélica tem por objeto os níveis do ser (1) e (2), compreende a pístis (a dóxa aristotélica) o nível do ser (3). Os outros níveis do ser - do (4) ao (6) - dizem respeito ao mundo suprassensível. A diánoia ou a epistéme aristotélica é confrontada com objetos matemáticos, nível do ser (4), ao passo que a nóesis ou o noũs lida tanto com o número, nível do ser (5) - o qual nesse contexto do relato, de acordo com o texto aristotélico, deve ser interpretado como ideia ${ }^{13}$ - quanto com os princípios opostos do Uno e da Díade Indeterminada, nível do ser (6).

As relações acima explicitadas podem ser resumidas no seguinte quadro:

\begin{tabular}{|c|c|c|c|c|}
\hline \multicolumn{2}{|c|}{ Faculdades da Alma } & \multicolumn{3}{|c|}{ Níveis do Ser } \\
\hline Platão & Aristóteles & Platão & Aristóteles & S. Empírico \\
\hline Nóesis & Noũs & $\begin{array}{c}\text { Ideias e Ideia do } \\
\text { Bem }\end{array}$ & $\begin{array}{c}\text { Unidade ou } \\
\text { ponto }\end{array}$ & $\begin{array}{c}\text { Uno e Díade Indetermi- } \\
\text { nada (6); Números (5) }\end{array}$ \\
\hline Diánoia & Epistéme & $\begin{array}{c}\text { Objetos matemá- } \\
\text { ticos }\end{array}$ & Linha & Linhas (4) \\
\hline Pístis & Dóxa & Objetos sensíveis & $\begin{array}{c}\text { Superfície } \\
\text { (Plano) }\end{array}$ & Superfícies (3) \\
\hline Eikasía & Aísthesis & $\begin{array}{c}\text { Imagens ou som- } \\
\text { bras das coisas } \\
\text { sensíveis }\end{array}$ & Corpo & $\begin{array}{c}\text { As figuras tridimen- } \\
\text { sionais (2); os corpos } \\
\text { sensivelmente perceptí- } \\
\text { veis (1) }\end{array}$ \\
\hline
\end{tabular}

O papel mediador da matemática torna-se bastante evidente, na medida em que ela atua como uma espécie de dobradiça entre os planos suprassensível e sensível, entre as ideias e os fenômenos. Em comum com o mundo suprassensível os objetos matemáticos têm imobilidade e eternidade, ao passo que a sua comunidade com o mundo sensível reside no fato de que há muitos exemplares semelhantes dos objetos matemáticos. A ideia, ao contrário, é somente uma. ${ }^{14}$ Não por acaso, a matemática ocupa um lugar importante no pensamento de Platão e está estreitamente relacionada com sua ontologia. Os matemáticos, no entanto, não consideram necessário dar razão (lógon didónai) 
dos pressupostos (hypostáseis) de sua ciência tanto a si mesmos quanto a outros. O conhecimento dianoético, juntamente com a imaginação e a crença, são, portanto, deficientes e têm de dar lugar a um outro saber capaz de não mais sucumbir às deficiências dessas três faculdades. Esse saber é a nóesis, a qual, ao partir das hypostáseis, alcança o anypótheton: aquilo que não mais carece de pressupostos para ser e ser explicado. Eis aí a última estação cognitiva alcançada pelo filósofo ${ }^{15}$ ou pelo dialético. ${ }^{16}$ Ela caracteriza o que é especificamente pertinente à filosofia, que, em razão do poder de desempenho cognitivo da nóesis, se distingue de outras formas de saber.

Assim sendo, é claramente exposto por Platão que o filósofo não só exerce, de forma apropriada, eikasía, pístis e diánoia, particularmente porque ele apresenta as inconsistências de suas pretensões a um saber irrefutável, mas também e principalmente exercita, em seu grau máximo de excelência, a mais potente (nóesis) das faculdades da alma. Ao exercitar com maestria as faculdades da alma, o filósofo se mostra como um profundo conhecedor de sua própria alma e da alma alheia. Consequentemente, ele se encontra na melhor posição para educar os seres humanos para o melhor uso das faculdades da alma, justamente porque ele já percorreu todo o espectro dos pathémata da alma e conhece, portanto, tanto a especificidade de cada páthema quanto o objeto associado a cada páthema. Ora, é tarefa do filósofo, tal como Platão a compreende, o exercício do método dialético. Esse consiste em elevar os pressupostos (tàs hypothéseis anairoũsa) até o princípio (ep' autèn tèn archèn), que é anipotético e incondicionado, propiciando também ao olho da alma (tò tês psychês ómma) elevar-se da lama ao alto, ao plano supremo das ideias e daquilo que é seu princípio. O método dialético exige, portanto, a transcendência de níveis inferiores e deficientes do saber. Essa transcendência não significa, todavia, a extirpação daquilo que foi transcendido. Ao filósofo assim interpretado por Platão cabe a habilidade de transitar pelos pathémata da alma, sem deixar-se aprisionar pelos limites da eikasía, pístis, diánoia e da própria nóesis, enquanto o saber noético não atinge o ponto final de sua viagem onto- e gnoseológica.

As passagens acima referidas do texto de Sexto Empírico sobre a doutrina não-escrita de Platão e do diálogo $A$ República expressam os significados envolvidos em synanaireĩsthai. O ser-conegado dos níveis inferiores e posteriores do ser mediante o ser-negado do nível superior e anterior, tal como ele foi explicado no relato de Sexto Empírico, é a contraparte dialética descendente da dialética ascendente da alma, tal como mostrada no diálogo. 
$\mathrm{Na}$ dialética ascendente, o elevar os pressupostos ao princípio anipotético apresenta uma transcendência que é, simultaneamente, imanência; uma negação que é, simultaneamente, preservação e conservação do que foi negado: o sercopreservado. Ao transitar pelos níveis do ser, por exemplo, dos fenômenos aos objetos matemáticos, o nível transcendido ou negado não está eliminado pelo novo nível afirmado, o qual, então, vem a ser o novo e imanente horizonte de ação da alma, até o momento em que ele seja mais uma vez transcendido.

O texto de Sexto Empírico, por um lado, acentua o caráter negativo de synanaireĩsthai, porque ele, de acordo com Gaiser, em primeiro lugar, tematiza a construção dos níveis do ser, desde as figuras tridimensionais até o par "Uno e Díade Indeterminada", e porque, em segundo lugar - se levarmos em consideração, em uma perspectiva descendente, os níveis do ser - também a dependência do nível posterior em relação ao nível anterior é demonstrada. O texto escrito de Platão, por outro lado, sublinha tanto o caráter negativo quanto o "conservador" de synanaireĩsthai, porque ele investiga o percurso da alma que simplesmente não se desfaz do páthema negado, mas também o carrega em sua viagem "para cima".

O caráter negativo de synanaireĩsthai até então destacado no relato de Sexto Empírico é, no entanto, unilateral, porque ele foca a atenção apenas no ser-conegado do nível subordinado mediante o ser-negado do nível superior. Se, no entanto, prestarmos atenção ao nível posterior e subordinado, então constatamos que ele possui também negação e preservação, como este é também o caso no texto de Platão. Negação, na medida em que a composição dos elementos formadores de um determinado nível do ser supera esses elementos enquanto tais, como, p. ex., a composição da linha, a saber, o plano, nega as linhas enquanto tais, ou como, p. ex., a composição das sílabas, $i$. e., a palavra, não mais pode ser igualada às meras sílabas enquanto tais. Preservação, na medida em que a estrutura do nível posterior e subordinado contém em si o todo do nível anterior e supraordenado, enquanto esse todo atua como componente do nível posterior e subordinado, como p. ex. o plano tem em si as linhas como seus componentes.

\section{Hegel: Aufheben}

Em seu comentário ${ }^{17}$ à filosofia de Platão, Hegel, primeiramente, qualifica o próprio Platão como "um dos indivíduos histórico-mundiais" e 
sua filosofia como "uma das existências histórico-mundiais", em razão da "influência extremamente significativa" por ela exercida na "formação e desenvolvimento do espírito", pelo menos do espírito ocidental, acrescentaria. Em segundo lugar, ainda dentro de um contexto introdutório de caracterização do pensamento platônico como um todo, Hegel aponta para o elemento específico da filosofia platônica, a saber, "a elevação da consciência ao reino espiritual", "o direcionamento [da consciência, LAV] ao mundo intelectual, suprassensível". ${ }^{18}$ Isto é propriamente o que no texto platônico é denominado "segunda navegação" ${ }^{19}$ em oposição à consciência direcionada exclusivamente ao âmbito empírico, sensível e material. Em terceiro lugar, Hegel mostra-se convicto de que a filosofia platônica encontra-se plenamente explicitada nos diálogos, não havendo, portanto, uma doutrina esotérica, não-escrita e oral, capaz de complementar e esclarecer o que nos diálogos não é resolvido ou meramente aludido de forma obscura. ${ }^{20}$

Em virtude disso - e justamente em oposição aos estudos do novo modelo interpretativo da filosofia platônica que levam em conta os relatos sobre a doutrina oral e discutem o saber como sistema em Platão ${ }^{21}$ - Hegel, em quarto lugar, constata a ausência de "uma exposição sistemática da filosofia" em Platão, pois "a formação (Bildung) filosófica de Platão ainda não estava madura para isso [apresentação sistemática do discurso filosófico, LAV]". Somente Aristóteles chegou à "exposição científica e sistemática" do saber filosófico. ${ }^{22}$ A imaturidade da paideia filosófica de Platão não é, todavia, resultado de fraquezas do indivíduo Platão, mas de uma deficiente determinação da ideia mesma, i. e., de uma limitação histórica no exercício da própria filosofia, cuja face mais visível é a mistura (Vermischung) entre representação (Vorstellung) - o mito - e o conceito (Begriff) ou o puro pensar. Platão lança mão frequentemente de fábulas e figuras do mundo sensível para explicar aquilo que, na perspectiva de Hegel, é tarefa do puro conceito. O mito, enfatiza Hegel, é apenas uma "pedagogia do gênero humano", 23 um instrumento didático para aquela fase da história humana na qual "o pensamento ainda não é livre" 24 - livre dos contos fabulosos, fantásticos, das representações sensíveis e, com isto, movendo-se na sua própria esfera. Essa 
mistura dificulta, pois, aquela "exposição sistemática da filosofia" exigida pelo puro conceito, já que "não há qualquer critério (Maßtab), se o objeto [que se encontra sob investigação, LAV] está esgotado ou não". ${ }^{25}$ Restam, pois, no final sempre incompletude e aporia.

Ao mesmo tempo que não constata uma organização sistemática do saber filosófico em Platão, a qual permite à filosofia ser uma enciclopédia do saber, $i$. e., uma formação circular oriunda do próprio conteúdo do saber em sua dinâmica imanente, afirma Hegel, de modo surpreendente, que "em seus discursos orais" (in seinen mündlichen Reden) Platão adota um procedimento sistemático. ${ }^{26}$ Ele também salienta que "a obra dogmática de Platão sobre as ideias", $i$. e., a dialética dos pensamentos puros, a qual é acompanhada pelo páthema da nóesis, está perdida, ${ }^{27}$ embora haja uma espécie de compensação para essa perda, a saber, os escritos Parmênides, Sofista e Filebo, nos quais a dialética dos pensamentos puros é abordada, fazendo desses escritos os mais difíceis dentre os textos platônicos. Se Hegel, de fato, estava ciente da tradição indireta dos ensinamentos orais de Platão, como o texto dessas Preleções sobre a história da filosofia testemunha, ${ }^{28} \mathrm{Hegel}$, todavia, não conseguiu obter uma visão da sistematicidade do pensamento de Platão, como o novo paradigma de pesquisa sobre a filosofia de Platão, graças ao estudo daquele material, pode agora apresentá-la. A este ponto voltarei de forma mais detalhada na sequência do texto.

Em seu comentário, ele adota uma abordagem da filosofia platônica tomando como base a organização do seu próprio sistema de filosofia. Assim sendo, a filosofia especulativa ou lógica corresponde à dialética, a filosofia da natureza encontra-se formulada particularmente no Timeu e, finalmente, filosofia do espírito tem também uma contraparte platônica assim dividida: a) a filosofia teórica do espírito: as "espécies de conhecimento" acima discutidas em A República; b) a filosofia prática do espírito: "exposição de um Estado perfeito" também em A República. ${ }^{29}$

Passo, então, ao tema da dialética, objeto de estudo desse trabalho. De uma maneira geral, Hegel reconhece na dialética platônica a coordenação das

25 HEGEL, VGPh, p. 27.

26 HEGEL, VGPh, p. 69.

27 Provavelmente, Hegel parece aludir, nesse contexto, ao ciclo de conferências ministradas por Platão, intitulado "Sobre o Bem", agora retomadas pelo novo paradigma interpretativo da filosofia de Platão como elemento indispensável para a compreensão de sua filosofia. Informações sobre a existência dessas palestras, bem como sobre os temas nelas abordados chegaram primeiramente até nós graças aos seus discípulos; vd. GAISER, 1998, p. 451-455; Testimonia Platônica, Nr. 7-11.

28 KRÄMER, 1994, p. 283 et seq.; n. 6, p. 284.

29 HEGEL, VGPh, p. 61. 
ideias entre si e também sua apreensão pelo páthema da nóesis. Avalia, porém, que Platão não está plenamente ciente do que é a "natureza da dialética" ${ }^{30} \mathrm{Em}$ que consiste, pois, essa deficiência de Platão acerca da "natureza da dialética"?

Primeiramente, ele critica a interpretação da dialética promovida pelo "filosofar formal", segundo a qual o que é próprio da dialética é confundir conceitos, de tal forma que o resultado seja meramente negativo. Essa é a dialética raciocinante (räsonierende Dialektik). Hegel está convicto de encontrar esse tipo de dialética também em alguns diálogos de Platão. Salienta, no entanto, que a dialética platônica não se resume a conclusões meramente negativas, mas também conduz à ciência das ideias, à dialética especulativa (spekulative Dialektik). Essa dialética negativa e raciocinante assemelha-se à dialética dos sofistas. ${ }^{31}$

Em segundo lugar, Hegel também constata uma outra dificuldade na compreensão da dialética platônica. Ela reside no fato de que a ideia no sentido platônico, filosoficamente traduzida por Hegel como universal (Allgemeines), gênero (Gattung) e espécie (Art), ${ }^{32}$ seja frequentemente exposta em associação com a representação, o sensível, a fim de levar a cabo a "transformação da opinião sensível no pensar", ${ }^{33}$ como tal transformação também é apresentada pela linha do saber acima descrita. O estreito vínculo entre ideia e representação, além de dificultar a compreensão da filosofia como sistema, como já dito acima, traz consigo um outro problema: ele dificulta o acompanhamento do pensamento que se move a si mesmo e em si mesmo, liberto das representações sensíveis, tal como os textos escritos da linha do saber e do método dialético explicitam, e tal como Hegel também fará na Ciência da Lógica.

Se, em Hegel, a Fenomenologia do Espírito tem como tarefa expor o movimento da consciência até aquele ponto "em que ela depõe sua aparência (Schein) de estar acometida com algo alheio que é apenas para ela e é como um outro" 34 e, portanto, abandona a posição de uma verdade em si, posta erroneamente como independente do saber, e, enfim, ela atinge o nível cognitivo necessário para acompanhar o movimento da ideia ou lógico em sua imanência (Ciência da Lógica) e, posteriormente, seu desdobramento na natureza (Filosofia da Natureza) e no espírito (Filosofia do Espírito), a alma,

30 HEGEL, VGPh, p. 61.

31 HEGEL, VGPh, p. 62; 64 et seq. Acerca das diferentes formas de dialética em Platão e Hegel v. Düsing 1995.

32 HEGEL, VGPh, p. 63.

33 HEGEL, VGPh, p. 62.

34 HEGEL PhG, p. 81. 
em Platão, por sua vez, eleva-se, através dos níveis do ser e conhecer, até o páthema da nóesis, o qual, então, lhe coloca em condições de lidar com as ideias em si mesmas e suas relações. Assim sendo, guardadas as devidas proporções e diferenças entre as filosofias de Platão e Hegel, é legítimo dizer que eikasía, pístis e diánoia correspondem ao que é exposto pela "ciência da experiência da consciência", a Fenomenologia do Espírito, e cumprem, pois, funções análogas àquelas exercidas pelas figuras da consciência.

Tanto em um caso - na Fenomenologia, através do "caminho da dúvida" e "o caminho do desespero" 35 - como também no outro - na filosofia de Platão, mediante a dialética raciocinante, segundo a terminologia de Hegel - cada novo e superior plano de evolução da alma ou consciência implica uma melhoria no próprio saber, de tal forma que o ápice do saber não é alcançado imediatamente, mas exige várias mediações e estações. Em Platão, as insuficiências da eikasía e pístis são tematizadas na passagem da primeira para a segunda navegação no Fédon (95a - 99d). Nesse contexto, ele procura evidenciar os problemas insolúveis advindos de uma interpretação do ser restrita exclusivamente ao mundo da dóxa. Em $A$ República, a segunda navegação é aprofundada mediante a identificação das deficiências do discurso matemático, que exigem, por sua vez, a passagem para o plano das ideias e da Ideia do Bem, acima da qual, portanto, nada mais pode ser pressuposto. Com isto, a jornada da alma alcança seu termo final. Em Hegel, as figuras da consciência são marcadas também por deficiências. Afinal, sem elas não haveria sentido transitar de uma figura para a outra. Assim, p. ex., a opinião da certeza sensível não se sustenta, porque defende um saber puramente imediato acerca de um objeto também por ela interpretado como pura imediatez. Desta opinião insatisfatória resulta, então, a percepção, capaz de suprassumir a opinião mediante o fato de que são aceitos tanto o imediato defendido pela certeza sensível quanto o mediatizado confirmado, de fato, na experiência, mas refutado pela opinião.

A experiência da consciência, bem como Ciência da Lógica, Filosofia do Espírito e Filosofia da Natureza, testemunham a "negação determinada" ${ }^{36}$ Cada nível de desenvolvimento produzido nessas esferas obedece ao ritmo do "suprassumir" (Aufheben): "negar" (Negieren) und "conservar" (Aufbewahren). ${ }^{37}$ Ele faculta a passagem de um nível determinado de desenvolvimento para um outro, evita a parada do movimento e a pura negação que conduz ao nada, a nenhuma nova forma de manifestação da consciência, 
do lógico, da natureza e do espírito. Nessas linhas bem gerais, corresponde o suprassumir àquilo que synanaireĩsthai expressa. Ambos expressam uma rede de relações que fomentam o avanço, novas configurações daquilo que aí se movimenta, mas também constroem vínculos com o já superado e, com isso, deixam surgir um todo bem estruturado.

Vencida, ao final da experiência fenomenológica da consciência, a ilusão de uma verdade alienada do saber - isto é justamente o saber absoluto a consciência está, então, apta a acompanhar o movimento da ideia em si mesma, enquanto objeto daquilo que Hegel denominava, em sua interpretação de Platão, dialética especulativa. As figuras da consciência são agora objeto da rememoração interiorizante (Erinnerung) ou do seu ir-para-dentro-de-si (Insichgehen), ${ }^{38}$ nos quais a consciência conserva (aufbewahrt) as figuras já ultrapassadas, enquanto elas são a existência desaparecida (verschwundenes Dasein) e, portanto, negada da consciência ou do espírito. Livre de uma vida que não mais corresponde a seu conceito, a consciência não lida com a ideia refletida nas figuras da consciência, mas com a própria ideia, o lógico apartado de sua presença no sensível.

A alma, por seu turno, para lembrar a imagem utilizada por Platão, inicialmente com os olhos atolados na lama, faz prevalecer a visão que the é própria, quando enfraquece seus laços com o corpo e recorda-se das ideias contempladas antes de sua união com o corpo. O olho da carne deve dar lugar ao olho da alma, a fim de que a epistéme substitua a dóxa. A união do corpo com a alma sempre forma, no entanto, um obstáculo para um verdadeiro conhecimento dos objetos, produzindo, principalmente, nos pathémata da diánoia e nóesis uma limitação de sua atuação. A recordação (anámnesis) ${ }^{39}$ das ideias é, pois, o antídoto contra a cegueira promovida pela dóxa. ${ }^{40}$ Daí, portanto, mais uma razão para o "filósofo verdadeiro" não temer a morte, pois nela o corpo físico deixa de ser empecilho para o conhecimento obtido pela alma. $^{41}$

Hegel, porém, interpreta a anámnesis (Wiedererinnerung) no sentido platônico, com base em sua própria filosofia, como sendo um Insichgehen. ${ }^{42}$ Ainda segundo a mistura da representação e do conceito ou do sensível e do inteligível, ele observa que a Wiedererinnerung tem um sentido empírico, de acordo com o qual ela é uma reprodução de algo acontecido em outro tempo. 
Essa recordação empírica, a qual também já fora rejeitada por Platão, não é, todavia, a recordação tal como interpretada pelo conceito. Assim como já havia feito na Fenomenologia, e sublinhando o movimento do conceito já liberto do sensível, Hegel insiste no significado de Erinnerung, do ponto de vista etimológico ou do "sentido profundo do pensamento da palavra", como Insichgehen, "fazer-se-interno" (Sich-innerlich-machen). Em virtude disso, mediante uma análise que também nos recorda o movimento da consciência na Fenomenologia, Hegel interpreta o movimento da alma pelos seus pathémata como um ir-para-dentro-de-si-mesma, de tal forma que ela "[...] suprassume essa aparência (Schein) do ser-outro (Schein des Andersseins) [...] e, assim, chega à ciência", ${ }^{43}$ neste caso, à ciência da ideia, à dialética especulativa.

Ir-para-dentro-de-si significa, portanto, a passagem da exterioridade à interioridade, da representação ao conceito, da alma ao espírito. ${ }^{44}$ Sua natureza é o "ser-em-si" (Bei-sich-Sein), "permanecer-em-si" (Bei-sich-Bleiben), ${ }^{45}$ que é também o objeto da dialética especulativa. Durante o trânsito de um ponto a outro e antes de sua chegada ao termo final, a saber, ao espírito ou ao conceito, tem lugar aquilo que Hegel sempre observa em seu comentário à filosofia de Platão: a mistura do mito com a razão. No caso em questão, o mitológico consiste na tese da transmigração da alma (Seelenwanderung), ${ }^{46}$ uma vez que a amnésia e anamnésia das ideias por parte da alma pressupõem a sua peregrinação a) em vários corpos e b) em um mundo post-mortem. Em razão disso, é óbvio que Hegel não precisa lançar mão da transmigração da alma para explicar a rememorização interiorizante das figuras da consciência. A rememoração, enquanto interiorização, é, pois, a passagem do mundo fenomênico (Erscheinungswelt) para a efetividade (Wirklichkeit) da ideia, ideia sempre presente mesmo que turvada por representação e mito. ${ }^{47}$ Hegel considera, portanto, a transmigração da alma como um artifício míticopedagógico para a elevação da dóxa à epistéme e não uma verdade da razão. A mistura de mito e razão é favorável a Hegel, na medida em que lhe permite, por um lado, caracterizar como mito aquilo (transmigração da alma) que the parece indefensável, ao passo que, por outro lado, ele podia considerar como racional outras teses de Platão, p. ex. a imortalidade da alma.

Diferentemente da transmigração da alma, relegada por Hegel ao mundo do mito, a imortalidade da alma, reconhecida por ele como guardando estreito 
vínculo com a metempsicose, é por ele admitida, justamente em virtude do fato de que ela está associada ao pensamento puro, ao conceito, ao universal, ao gênero e à ideia. ${ }^{48}$ Mutabilidade e transformação significam que um determinado objeto se perde no ser-outro e na alteridade. A passagem pela alteridade é sua destruição. O eterno, ao contrário, é justamente aquilo que no ser-outro, na alteridade permanece em si e junto a si. A alma é eterna, justamente porque "ela é [...] o manter-se-a-si-mesma no outro" (das Sichselbst-Erhalten im Anderen), ${ }^{49}$ principalmente no exercício do pensamento, substância e essência da alma. A atividade do pensamento puro, livre das representações e do mito, é, na verdade, a espiritualização da alma, a alma elevada ao espírito. A interpretação hegeliana considera o movimento da alma pelos seus pathémata como progresso da dialética raciocinante para a especulativa, da dóxa para a epistéme, do mito ao logos, como reconhecimento da alma enquanto espírito eterno.

Platão, finalmente, dá o passo em direção ao universal em si mesmo, no qual as oposições são postas, mas também dissolvidas chegando-se a um resultado positivo: à "dialética especulativa", movendo-se no terreno do puro pensar. Hegel deixa vir à luz a "coisa principal" ("Hauptsache") frequentemente negligenciada, "a única coisa interessante" (allein Interessante) também frequentemente esquecida, do seguinte modo: "o Mesmo (Dasselbe), o Idêntico a si mesmo (das mit sich Identische) é aquilo que é o Outro (das Andere); também o Mesmo é o Outro, o Não-Idêntico a si mesmo (das nicht mit sich Identische); o Igual a si mesmo (das Sichselbstgleiche) é também o Outro, e, na verdade, em uma e mesma referência". ${ }^{50}$ Os elementos opostos não são desacoplados um do outro, não são separados e isolados e referidos um ao outro de um modo superficial e externo. Eles passam um no outro; um torna-se, a partir de si mesmo, aquilo que o outro é, e vice-versa. Tomando a Ciência da Lógica como exemplo, o ser passa ao não-ser e vice-versa, de tal forma que o vir-a-ser (Devir) resulte desse processo. A "dialética especulativa" constitui o que Hegel, na filosofia de Platão, considera como "o esotérico" (das Esoterische): essa dialética é, no entanto, esotérica, não porque ela seja desenvolvida tão somente na sua comunicação oral e, em virtude disso, permaneça inacessível ao público extra-acadêmico, já que Hegel identifica-a também nos diálogos Parmênides, Sofista e Filebo. Daí, então, a conclusão

50 HEGEL, VGPh, p. 76. Nesse contexto, Hegel retoma a tradução de uma passagem do Sofista (539 c-d) feita anteriormente (HEGEL, VGPh, p. 72). Os eventuais problemas envolvidos nessa tradução (v. acerca desse tema: DÜSING, 1995, p. 188) não pretendo aqui detalhar. 
de Hegel, segundo a qual a diferença entre esotérico e exotérico é uma "má diferença". ${ }^{51}$

Afinal, a relação do filósofo com as ideias por ele defendidas não é a mesma que se estabelece entre o ser humano e as coisas do mundo que ele pode ou não esconder "no bolso". Entre o pensamento ou a ideia, de um lado, e o ser humano, de outro, tem lugar uma relação de posse: "A ideia filosófica possui $[. .$.$] o ser humano". { }^{52}$ Em virtude disso, argumenta Hegel, um filósofo não pode deixar de expressar em seus escritos o pensamento possuidor do homem. A dialética especulativa, portanto, não está ausente dos escritos. Ao contrário, ela encontra-se escrita e inscrita nos diálogos, embora como um elemento recôndito (ein Verborgenes), não acessível a todos, porque nem todos se esforçam para transitar da dialética raciocinante para a dialética especulativa.

Nesse sentido, a estrutura sistemática do saber, atribuída também por Hegel aos ensinamentos orais de Platão, não pode ser retirada dos diálogos de Platão, já que Platão, como filósofo, e um filósofo de estatura históricomundial, não poderia, por assim dizer, guardar seus pensamentos "no bolso" e comunicá-los tão somente a um público intra-acadêmico e esotérico. Eles seriam dissimulados pela dialética raciocinante e retirados do contexto público e exotérico através de pretextos tais como os limites do texto escrito. Portanto, mesmo que Hegel reconheça o esotérico e o sistemático nos ensinamentos orais de Platão, e mesmo que levemos em conta as restrições expressas pelo próprio Platão ao escrito, ${ }^{53}$ o pensamento de Platão tem necessariamente de vir a lume, ser exotérico e público, uma vez que, se "a ideia filosófica possui o ser humano", isso é ainda mais efetivo para um filósofo, particularmente para um filósofo como Platão.

Hegel, no entanto, não consegue reconstruir a sistematicidade do pensamento de Platão, porque o acesso ao material intra-acadêmico lhe estava acessível apenas parcialmente, já que o material organizado por Brandis sobre o ensinamento oral de Platão veio à luz somente em 1823, cerca de oito anos antes da morte de Hegel. ${ }^{54}$ Pois, embora Platão não pudesse evitar as referências mais ou menos expressas ao não-escrito em seus escritos, como o próprio Hegel admite, a não-autonomia dos escritos diante do ensinamento oral impediu uma compreensão global do saber filosófico platônico, compreensão 
essa baseada apenas nos textos escritos. As alusões ao não-escrito eram, contudo, tão áridas, que em muito se distanciavam de propiciar uma visão geral do sistema do saber e do ser em Platão. Isto torna-se bastante evidente no fato de que Hegel não consegue reconstruir a composição dos níveis do ser correspondentes aos modos de conhecimento da alma. Diante da relação de analogia identificada por Gaiser entre as dimensões espaciais, os níveis objetivos do ser e a estrutura subjetiva da alma, as afirmações minimalistas de Hegel são bastante insatisfatórias, simplificadoras e estão aquém da complexidade do objeto investigado. Além disso, como veremos a seguir, ele projeta na dialética platônica teses estranhas a essa dialética.

Finalmente, depois de reconhecer a dialética especulativa e aproximála da dialética da ideia, tal como exposta em sua Ciência da Lógica, Hegel, por seu turno, aponta as limitações da dialética especulativa. Elas residem no fato de que o movimento de reflexão do Uno e múltiplo, do mesmo e outro, do ser e não-ser frequentemente tem lugar de acordo com "considerações externas", ${ }^{55}$ segundo o modo da representação, ao invés de apresentá-lo como um movimento imanente, no qual o próprio uno vem a ser o múltiplo, e o múltiplo, por sua vez e reciprocamente, torna-se o uno. Em virtude dessa oscilação entre imanência e exterioridade, da mistura entre mito e conceito e da falsa identificação da dialética raciocinante com a dialética especulativa identificação cuja responsabilidade, em parte, deve ser creditada ao próprio Platão - Hegel não a reconhece como completa, consumada e perfeita (vollendet). ${ }^{56}$

O comentário de Hegel sobre a filosofia de Platão não poderia ocorrer independentemente do sistema de filosofia hegeliano, como o demonstra a própria divisão do comentário. Por isso, não é de se estranhar que a dialética especulativa platônica seja interpretada segundo a perspectiva da filosofia especulativa ou lógica hegeliana. Ora, Hegel considera a ideia, enquanto ela se encontra em uma de suas manifestações determinadas, como "um momento fluente" (ein fließendes Moment) ${ }^{57}$ que não se detém em uma das suas finitas e provisórias etapas de desenvolvimento e aí, por assim dizer, se petrifica. O "momento dialético" da ideia, enquanto essa possa ser interpretada como um fluir, é o "passar" (Übergehen) de uma determinação finita para uma outra determinação finita oposta. ${ }^{58} \mathrm{O}$ fluir da ideia, de tal forma que 
uma determinação da ideia passa à determinação oposta, e vice-versa, não parece, todavia, traduzir convincentemente a dialética especulativa platônica. Pois, ao comentar o relato de Sexto Empírico supra referido, Gaiser chama a atenção para uma diferença, já identificada pelo próprio Sexto Empírico, entre os antigos e novos pitagóricos acerca dos dois modos de compreensão da construção dos níveis do ser. ${ }^{59}$

Essa diferença é reinterpretada por Gaiser de tal modo que ele atribui à posição de Platão o tipo de abordagem dos primeiros pitagóricos, ao passo que ele tem boas razões para corresponder à posição de Espeusipo ao ponto de vista dos novos pitagóricos. Este considera os corpos como resultado de um fluir (rhyén, rhyeĩsan) que tem no ponto seu início. Este, por sua vez, mediante seu fluir gera a linha, a qual, por seu turno, também através do seu fluir faz surgir a superfície ou plano, e este, finalmente, movido até a profundidade, produz os corpos tridimensionais.

Segundo o modo de abordagem de Espeusipo, cujo sistema também já foi comparado ao de Hegel, ${ }^{60}$ o fluir de um único princípio, a saber do ponto, origina os vários níveis do ser. Diferentemente, os "primeiros pitagóricos", relata Sexto Empírico - na verdade, Platão, corrige Gaiser - fazem surgir números, pontos, linhas, etc. a partir do Uno e da Díade Indeterminada, portanto, a partir de dois princípios opostos. De acordo com essa concepção, o Uno não vem a ser o seu oposto, a Díade Indeterminada, e essa, por sua vez, não torna-se o Uno. Não há, portanto, o fluir do Uno, o qual, por sua vez, engendra a Díade Indeterminada, ou o fluir da Díade Indeterminada que gera o Uno. Os vários planos do ser são oriundos da ação determinante do Uno sobre a indeterminação da Díade, de tal forma que cada um dos vários planos do ser, moldados através dessa relação, constitui um modo específico e original de articulação desses princípios opostos.

Não se trata, nesse contexto, de "um simples processo de crescimento", de um processo orgânico tão caro à filosofia de Hegel, mas de "um processo de formação (Formierung)", ${ }^{61}$ no qual o Uno, o princípio determinante, desempenha o papel de um elemento formador e configurador diante do princípio indeterminado. Mesmo que ambas as posições sejam, de algum modo, combinadas e consideradas também como teses de Platão, de tal forma que a Díade Indeterminada engendre a próxima dimensão mediante o fato de que ela "efetive em si, a cada vez, uma extensão que flui para a próxima 
dimensão", ao passo que o Uno limita a nova dimensão assim surgida, como o próprio Gaiser admite, ${ }^{62}$ a interpretação de Hegel é indefensável. Pois, a "extensão que flui para a próxima dimensão", extensão levada a cabo pela Díade Indeterminada, não exclui o processo de formação, o qual pressupõe dois princípios opostos que não se transformam um no outro. ${ }^{63}$

Interessante observar que Hegel vê no Filebo, um dos diálogos que apresenta a dialética especulativa, a relação entre péras e apeíron. ${ }^{64} \mathrm{O}$ breve comentário de Hegel a esse diálogo mostra, contudo, a ambivalência da leitura hegeliana. De um lado, bem ao estilo daquilo que relata Sexto Empírico, Hegel constata que saúde, calor, frio, etc. são resultado da unidade dos opostos péras e ápeiron. Está também consciente da determinação de péras sobre o ápeiron. De outro lado, no entanto, ele deixa transparecer sua tese do fluxo do lógico ou da ideia na própria tradução de péras.

Além de traduzi-lo como "finito", "limite", "limitante", "proporção" e "medida", em oposição a ápeiron, "infinito", "indeterminado" e "ilimitado", ele ainda o traduz como "aquilo-que-se-determina-a-si-mesmo" (das Sichselbstbestimmende). ${ }^{65}$ Péras não é, pois, o que determina o seu oposto: o indeterminado, "o que é capaz de ser mais ou menos, o que pode ser ou não mais intensivo: mais quente, mais seco, mais húmido, etc". O finito é, ao contrário, na interpretação hegeliana, "a determinação livre imanente", ${ }^{66}$ não a determinação de um oposto, mas de si mesmo. Ora, ele pode ser a determinação de si, se e somente se o Absoluto é interpretado como "aquilo que é finito e infinito em uma unidade": ${ }^{67}$ o Absoluto ou Infinito dá a si mesmo, exclusivamente a partir de si mesmo, uma forma finita, a qual, no entanto, em razão de sua própria inconsistência e contradição, exige e fomenta a passagem para uma outra forma finita. Hegel, portanto, identifica sua interpretação do Absoluto como unidade do infinito e finito e a relação de imanência entre ambos com a relação entre péras e apeíron, em que eles são irredutíveis um ao outro, não são mais momentos opostos que se transformam e passam um no outro.

O processo de formação a partir de princípios opostos e o processo do passar e fluir de determinações opostas uma na outra expressam duas posições diferentes, se o texto de Sexto Empírico acima citado e sua interpretação por 
Gaiser são levados em consideração. A interpretação hegeliana da dialética especulativa platônica já pode ser questionada mediante o fato de que a passagem do diálogo Filebo comentada pelo próprio Hegel mostra uma outra maneira de acompanhar o movimento dialético. De fato, a posição de Hegel é correta, na medida em que o texto escrito de Platão tem de trazer à luz seu pensamento - também aqueles que foram comunicados em seu ensinamento oral. No entanto, o pensamento de Platão cunhado nos escritos não mostra o todo de seu pensamento, o qual Hegel, em virtude de sua limitação ao texto escrito, não pode mais reconstruir. A alusão ao ensinamento oral de Platão não só aprofunda e evidencia a diferença entre as dialéticas platônica e hegeliana em parte já identificável em alguns escritos (p. ex. no Filebo), mas também esclarece (1) a complexa construção dos níveis do ser, sua articulação com as faculdades de conhecimento da alma e (2) uma reação intra-acadêmica, provavelmente levada a cabo por Espeusipo à posição de Platão. Essa reação, que guarda, por seu turno, uma certa semelhança com a filosofia de Hegel, testemunha um posterior desenvolvimento das teses de Platão. Nesse sentido, a dialética de Hegel mostra-se como continuação de uma das variantes de avaliação da filosofia platônica iniciadas já dentro da própria academia.

Além de outros aspectos da dialética platônica e hegeliana que aqui foram intencionalmente negligenciados, permanece ainda uma interessante tarefa a ser empreendida: a avaliação das consequências dessas diferenças nas esferas do espírito e da natureza.

\section{Referências}

ARISTOTELES. Metaphysik. Bücher I (A) - VI (E). Griechisch-Deutsch. Hamburg: Felix Meiner, ${ }^{3} 1989$.

ARISTOTELIS. De anima. Oxford: Oxford University Press, 1956.

DIALEKTIK. In: RITTER, J.; GRUNDER, G. (Hrsg). Historisches Wörterbuch der Philosophie. Basel: Schwabe, 1971ff.

DÜSING, K. Hegel und die Geschichte der Philosophie. Darmstadt: Wissenschatliche Buchgesellschaft, 1983.

DÜSING, K. Formen der Dialektik bei Plato und Hegel. In: RIEDEL, M. (Hrsg.) Hegel und die antike Dialektik. Frankfurt a.M: Suhrkamp, ${ }^{6} 1995$. p. 169-191.

GADAMER, H. Hegel und die antike Dialektik. In: GADAMER, H. Hegels Dialektik: Fünf hermeneutische Studien. Tübingen: J. C. B. Mohr (Paul Siebeck), 1971. p. 7-30. GAISER, K. Platons Ungeschriebene Lehre. Studien zur systematishchen und geschichtlichen Begründung der Wissenschaften in der Platonischen Schule. Stuttgart: Klett-Cotta, ${ }^{3} 1998$. 
GAWOLL, H. Literaturverzeichnis. In: HEGEL, Georg Wilhelm Friederich. Wissenschaft der Logik: Erster Band: Die objektive Logik: Erstes Buch: Das Sein (1812). Hamburg: Felix Meiner, 1986. p. XLIX- LIII.

HEGEL, G. W. F. Phänomenologie des Geistes. Frankfurt am Main: Suhrkamp, 1996. (Bd. 3). (=PhG).

HEGEL, G. W. F. Wissenschaft der Logik. Frankfurt am Main: Suhrkamp, 1991. (Bd. 5). (=WL I).

HEGEL, G. W. F. Enzyklopädie der philosophischen Wissenschaften im Grundrisse. 1830. Frankfurt am Main: Suhrkamp, 1994. (Bd. 10). (=Enz I).

HEGEL, G. W. F. Vorlesungen über die Geschichte der Philosophie. Frankfurt am Main: Suhrkamp, 1991. (Bd. 19). (= VGPh).

KRÄMER, H. La teoria dei principi alla luce dell'hegelismo. In: KRAMER, H. Platone e i fondamenti della metafisica: saggio sulla teoria dei principi e sulle dottrine non scritte di Platone con una raccolta dei documenti fondamentali in edizione bilingue e bibliografia (Introduzione e traduzione del testo tedesco e dei testi greci di Giovanni Reale). Milano: Vita e Pensiero, ${ }^{5}$ 1994. p. 282-302.

PLATO. Werke in acht Bänden: Griechisch und Deutsch. Darmstadt: Wissenschaftliche Buchgesellschaft, 1990.

REALE, G. História da filosofia antiga II. São Paulo: Loyola, 1994.

REALE, G. Para uma nova interpretação de Platão. São Paulo: Loyola, 1997.

RIEDEL, M. (Org.) Hegel und die antike Dialektik. Frankfurt am Main: Suhrkamp, ${ }^{6} 1995$.

SEXTUS Empiricus. Against the physicists. In: SEXTUS Empiricus III. Against the physicists; Against the ethicists. Cambridge, Mass.: Harvard University Press; London: W. Heinemann, 1987. (Loeb classical library; 311).

VIEILLARD-BARON, J. Les leçons de Hegel sur Platon dans son histoire de la philosophie. Revue de Métaphysique et de Morale, 78, n. 3, juil.-sept. 1973, S. 385419.

VIEIRA, L. Liberdade, dialética e intuição intelectual. In: BRITO, E.; CHANG, L. (Org.). Filosofia e método. São Paulo: Loyola, 2002. p. 19-62.

VIEIRA, L. Synanaireĩsthai und Aufheben. Einige Aspekte der Platonischen und Hegelschen Dialektik. In: EIDAM, H.; HERMENAU, F.; SOUZA, D. (Hrsg.) Metaphysik und Hermeneutik. Festschrift Hans-Georg Flickinger zum 60. Geburtstag. Kassel: Kassel University Press, 2004. S. 15-34. 